\title{
Modification of The Ingenhousz Trial Tool to improve The EfFectiveness And Efficiency of Photosynthesis Learning in Class VIII-3 Students SMP Negeri 4 Palangka Raya
}

\section{Modifikasi Alat Percobaan Ingenhousz untuk Meningkatkan Efektifitas dan Efisiensi Pembelajaran Fotosintesis Pada Siswa Kelas VIII-3 SMP Negeri 4 Palangka Raya}

\author{
Unru Maleh \\ Guru SMP Negeri 4 Palangka Raya \\ e-mail : maleh1371@gmail.com
}

\begin{abstract}
The purpose of this study was to determine the effectiveness and efficiency of photosynthesis learning by using the modified Ingenhousz Experiment Tool that was made by researchers. The subjects in this study were students of SMP Negeri 4 Palangka Raya, grade VIII-3 Academic Year 2019/2020, with the total number of 23 students, consisting of 14 men and 9 women. Data collection for learning effectiveness was by using knowledge test sheets, performance and activities tests, while for learning efficiency by calculating the use of time in learning, product tests and questionnaires. Data on the effectiveness and efficiency of learning in the meeting-I and meeting-II were compared to determine the improvement. Based on the results of research, obtained that the use of the Ingenhousz Experiment Tool in photosynthesis learning resulted in an increase in learning outcomes, namely the average grade for knowledge rose from 56.69 to 80.86 . Grade completeness increased from $34 \%$ to $90 \%$. For the skills to carry out the experiment, the average grade increased from 63.00 to 78.52 and grade completeness skills rose from $22 \%$ to $95.65 \%$. While for the average value of student activity increased from 2.57 to 2.85 in the good category. The ability of students to make Ingenhousz experimental equipment was 76.21 which was included in a good category, while the students' response to the learning process reached of $89 \%$, which meant that the response of students was very good. The time spent could also be saved from 60 minutes to 45 minutes with the above results. It could be concluded that the modified Ingenhousz Experiment Tool increased the effectiveness and efficiency of the implementation of photosynthesis learning in grade VIII-3 of SMP Negeri 4 Palangka Raya.
\end{abstract}

Keywords: Modification, Ingenhousz experiment tool, effectiveness and efficiency

\begin{abstract}
ABSTRAK
Tujuan penelitian ini adalah untuk mengetahui bagaimana efektivitas dan efisiensi pembelajaran fotosintesis dengan menggunakan Alat Percobaan Ingenhousz hasil modifikasi yang dibuat oleh peneliti. Subjek dalam penelitian ini adalah siswa SMP Negeri 4 Palangka Raya kelas VIII -3 Tahun Ajaran 2019/2020 yang berjumlah 23 orang, terdiri dari 14 laki-laki dan 9 perempuan. Pengumpulan data untuk efektivitas pembelajaran menggunakan menggunakan lembar tes pengetahuan, tes kinerja dan aktivitas, sedangkan untuk efisiensi dengan menghitung penggunaan waktu dalam belajar, tes produk dan angket. Data efektivitas dan efisiensi belajar pertemuan I dan pertemuan II dibandingkan untuk melihat peningkatannya. Berdasarkan hasil penelitian yang dilakukan diperoleh bahwa : Penggunaan Alat Percobaan Ingenhousz pada pembelajaran fotosintesis mengakibatkan peningkatan hasil belajar yakni nilai rata-rata kelas untuk pengetahuan naik dari 56,69 menjadi 80,86 . Ketuntasan kelas naik dari $34 \%$ menjadi $90 \%$, untuk keterampilan melaksanakan percobaan nilai rata-rata kelas meningkat dari 63,00 menjadi 78,52 dan ketuntasan kelas keterampilan naik dari $22 \%$ menjadi $95,65 \%$. Sedangkan untuk nilai rata-rata aktivitas siswa meningkat dari 2,57 menjadi 2,85 pada kategori baik, kemampuan siswa dalam membuat alat percobaan Ingenhousz 76,21 masuk dalam kategori baik, sedangkan respon siswa terhadap proses pembelajaran mencapai $89 \%$ yang berarti respon siswa sangat baik. Waktu yang digunakan juga dapat di hemat dari 60 menit menjadi 45 menit dengan hasil diatas dapat disimpulkan bahwa Alat Percobaan Ingenhousz hasil modifikasi tersebut dapat meningkatkan efektifitas dan efisiensi pelaksanaan pembelajaran fotosintesis pada siswa kelas VIII-3 SMP Negeri 4 Palangka Raya.
\end{abstract}

Kata Kunci : Modifikasi, Alat Percobaan Ingenhousz, Efektivitas dan Efisiensi 


\section{PENDAHULUAN}

Pelaksanaan pembelajaran di kelas semestinya selalu mengalami perubahan ke arah yang lebih baik dari waktu ke waktu. Guru sebagai motivator dan fasilitator di dalam kelas selalu dituntut kreativitasnya untuk memvariasikan model pembelajaran yang digunakan, termasuk memodifikasi dan mengembangkan alat percobaan dengan demikian diharapkan pelaksanaan pembelajaran dengan model praktikum dapat berjalan secara efektif dan efisien.

Dalam pembelajaran IPA, kegiatan percobaan merupakan bagian integral dari kegiatan belajar mengajar. Kegiatan praktikum memiliki peranan yang besar dalam mencapai tujuan proses belajar mengajar. Woolnough \& Allsop (Rustaman:1995) mengemukakan empat alasan pentingnya kegiatan praktikum. Pertama, praktikum dapat membangkitkan motivasi belajar IPA; kedua praktikum dapat mengembangkan keterampilan dasar melakukan eksperimen; ketiga praktikum dapat menjadi wahana belajar pendekatan ilmiah; dan keempat praktikum dapat menunjang pemahaman materi pelajaran.

Tujuan pokoknya adalah membangun konsep dan mengkomunikasikan berbagai fenomena yang terjadi dalam pembelajaran IPA, serta mengatasi miskonsepsi karena siswa memperoleh konsep berdasarkan pengalaman nyata yang dapat mengembangkan kemampuan berpikirnya. Tujuan praktikum yang diungkapkan, tergambar bahwa praktikum memiliki beberapa fungsi sebagai berikut: memberikan kelengkapan bagi pelajaran teori yang telah diterima, sehingga antara teori dan praktikum bukan merupakan dua hal yang terpisah; memberikan keterampilan kerja ilmiah bagi siswa; memberikan dan memupuk keberanian untuk mencari hakekat kebenaran ilmiah dari suatu objek dari lingkungan alam dan lingkungan sosial, menambah keterampilan dalam menggunakan alat-media yang tersedia untuk mencari dan menemukan kebenaran; memupuk rasa ingin tahu siswa sebagai modal sikap ilmiah seorang ilmuwan; dan memupuk dan membina rasa percaya diri sebagai akibat keterampilan penemuan yang didapat dalam proses kegiatan laboratorium.

Untuk mencapai tujuan praktikum, kemampuan siswa untuk mengoperasikan alat percobaan sangatlah penting. Percobaan atau praktikum dapat berjalan dengan baik apabila siswa menguasai cara kerja praktikum, alat praktikum dari sisi kuantitas cukup untuk memenuhi kebutuhan siswa dan mudah didapat serta alat percobaan mudah digunakan oleh siswa. Kemampuan siswa untuk melaksanakan praktikum dan kemudahan dalam penggunaan alat praktikum akan memberi dampak pada efektifitas dan efesiensi pelaksanaan percobaan.

Dalam Pembelajaran Fotosintesis, salah satu praktikum yang dilaksanakan adalah percobaan Ingenhousz, percobaan ini untuk membuktikan bahwa hasil fosintesis adalah Oksigen. Dalam percobaan Ingenhousz siswa merangkai alat dan bahan guna menemukan fakta yang kemudian dihubungkan dengan konsep materi fotosintesis. Adapun alat yang di gunakan adalah yang tabung reaksi, Gelas kimia besar, corong kaca, kawat pengait. Alat-alat tersebut dirangkai seperti Gambar 1 di bawah ini :

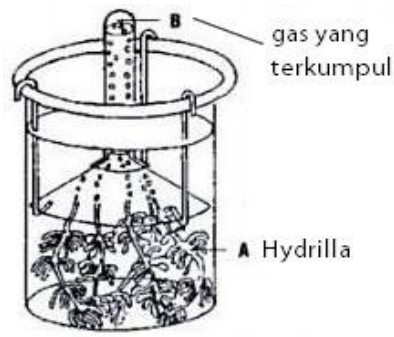

Gambar 1. Perangkat Percobaan Jan Ingenhousz

Pengalaman peneliti dalam Proses pembelajaran materi fotosintesis menggunakan metode praktikum yang salah satunya dengan melaksanakan percobaan Ingenhousz di kelas VIII-3 SMP 4 Palangkaraya ada beberapa kendala yang di hadapi yaitu alat-alat yang tersedia di Laboratorium untuk merangkai alat Percobaan Ingenhousz tidak mencukupi untuk semua kelompok praktikum, alat-alat yang dibutuhkan untuk praktikum tidak dapat disediakan oleh siswa karena cukup mahal dan disekitar tempat siswa sukar didapatkan, penggunaan waktu yang lama untuk merangkai alat rata-rata 15 menit dan secara keseluruhan waktu yang digunakan untuk percobaan ingenhousz mendekati 60 menit, bahkan terjadi kegagalan dalam merangkai alat dan bahan karena corong jatuh dari pengait, sambungan antara corong dan tabung reaksi terangkat ke atas air sehingga air dari dalam tabung reaksi keluar. Selanjutnya hasil tes kinerja praktikum 78\% (19 siswa) gagal merampungkan semua cara kerja percobaan karena ketika ingin membuktikan hasil fotosintesis adalah oksigen, siswa tidak dapat membalik dan menutup mulut tabung yang berada didalam air dengan baik sehingga gas ikut keluar. Sedangkan Hasil Uji Pengetahuan menunjukkan bahwa 73\% (17 siswa) tidak tuntas, dengan demikian pelaksanaan percobaan ingenhaousz untuk menemukan fakta hasil fotosintesis dan faktor yang mempengaruhi fotosintesis tidak tercapai dengan baik. 
Menghadapi kendala yang demikian, peneliti berusaha memodifikasi alat percobaan Ingenhousz dengan menggunakan bahan-bahan jadi di sekitar lingkungan tempat tinggal siswa. Bahan-bahan yang disiapkan kemudian dirangkai dan dikembangkan menjadi alat percobaan ingenhousz. Alat hasil modifikasi tersebut digunakan dalam praktikum Ingenhousz dengan harapan, semua siswa dalam pembelajaran dapat melaksanakan percobaan ingenshousz dengan benar, menemukan alasan serta menunjukkan fakta yang lebih meyakinkan kalau hasil fotosintesis adalah Oksigen dengan waktu yang relatif singkat dari peralatan yang murah dan mudah didapatkan. Dengan demikian praktikum dapat dilaksanakan secara efektif dan efisien.

\section{METODE PENELITIAN}

Jan Ingenhousz (1799) membuktikan bahwa pada fotosintesis dilepaskan $\mathrm{O}_{2}$. Hal ini dibuktikan dengan percobaannya menggunakan tanaman air Hydrilla verticillata di bawah corong terbalik. Jika tanaman tersebut kena sinar, maka timbulah gelembunggelembung gas yang akhirnya mengumpul di dasar tabung reaksi. Gas ini ternyata oksigen.
Perangkat Percobaan Ingenhousz ini sesungguhnya dirancang untuk memerangkapkan oksigen hasil fotosintesis untuk diarahkan oleh corong ke dalam tabung reaksi sehingga dalam selang waktu tertentu oksigen berkumpul di ujung tabung. Demikian juga bentuk rancang bangun alat Percobaan Ingenhousz hasil modifikasi yang ditunjukkan pada Gambar 2 ini bertujuan untuk memerangkapkan oksigen dan mengumpulkanya pada ujung tabung, akan tetapi jika perangkat percobaan Ingenhousz sebelumnya berupa perangkat percobaan dari alat-alat terpisah yang terbuat dari kaca, tetapi alat percobaan ingenhosz hasil modifikasi terbuat dari bahan bekas yang terbuat dari plastik dengan sedikit pengembangan. Adapun pengembangan yang dilakukan adalah menempatkan lubang pada ujung tabung yang bisa dibuka tutup, selain itu karena alat ini berupa alat utuh yang menyatu maka untuk mempermudah pelaksanaan maka posisi stoples sebagai pengganti gelas beaker di letakkan terbalik sehingga bagian mulut stoples dapat dibuka dan ditutup untuk memasukkan tumbuhan Hydrilla verticillata ke dalam alat percobaan Ingenhousz.

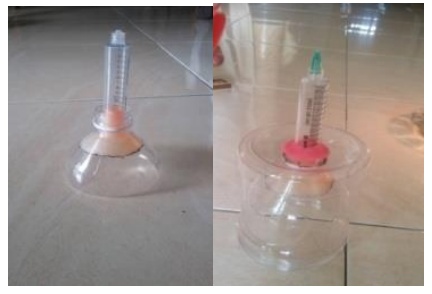

Gambar 2. Perangkat percobaan Ingenhousz Proses Pembaharuan
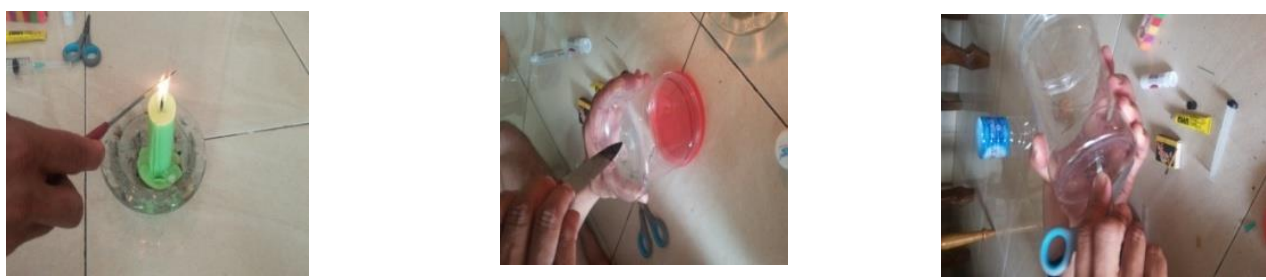

Gambar 3. Langkah ke-1 pembuatan alat percobaan Ingenhousz
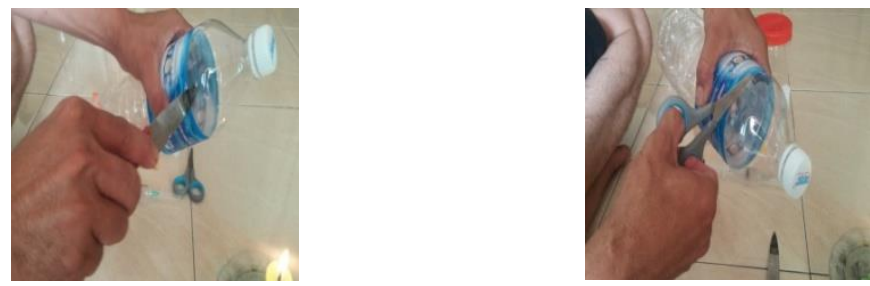

Gambar 4. Langkah ke-2 pembuatan alat percobaan Ingenhousz 


\begin{tabular}{|l|r|}
\hline Unru Maleh & Vol. 8 No. 1 Januari-Juni 2020:1-10 \\
\hline
\end{tabular}
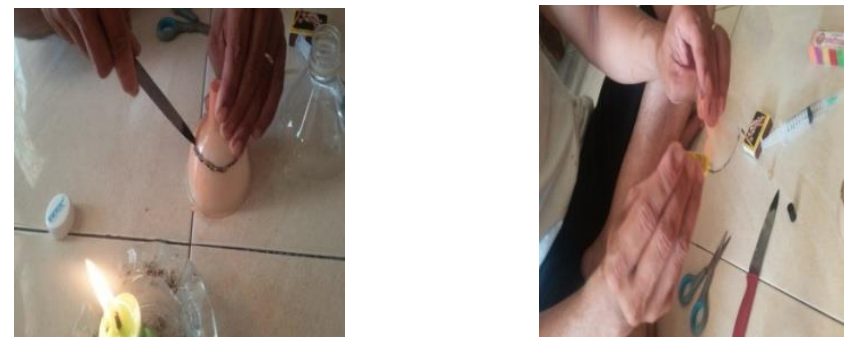

Gambar 5. Langkah ke-3 pembuatan Alat Percobaan Ingenhousz
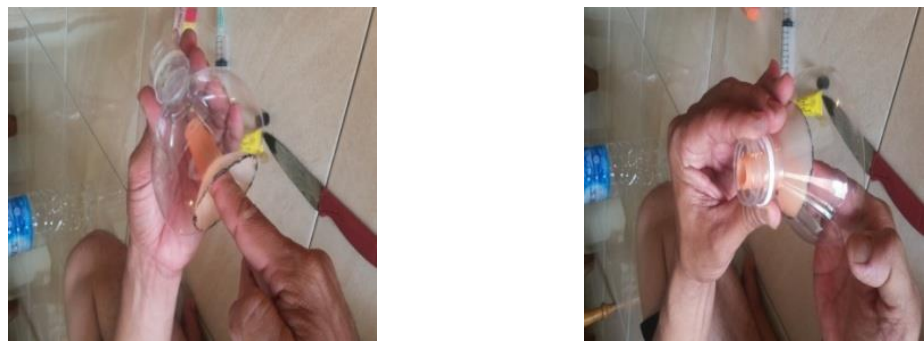

Gambar 6. Langkah ke 4 pembuatan alat percobaan Ingenhousz
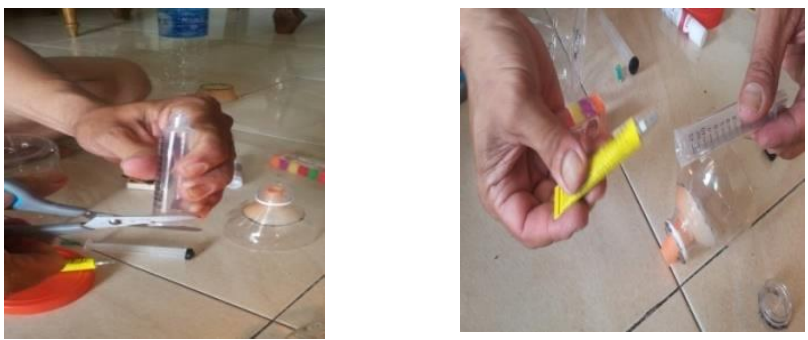

Gambar 7. Langkah ke-5 Pembuatan alat Percobaan Ingenhousz
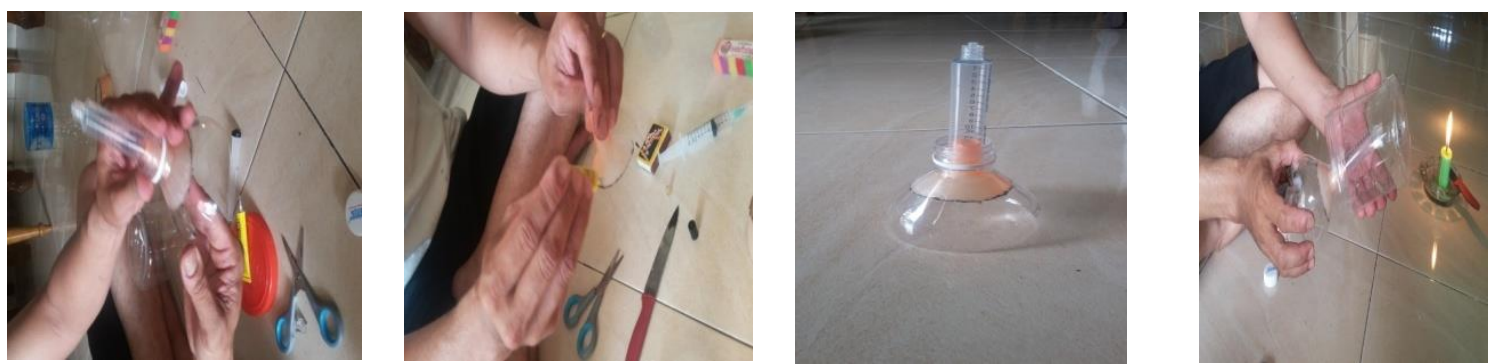

Gambar 8. Langkah ke-6 pembuatan alat percobaan Ingenhousz
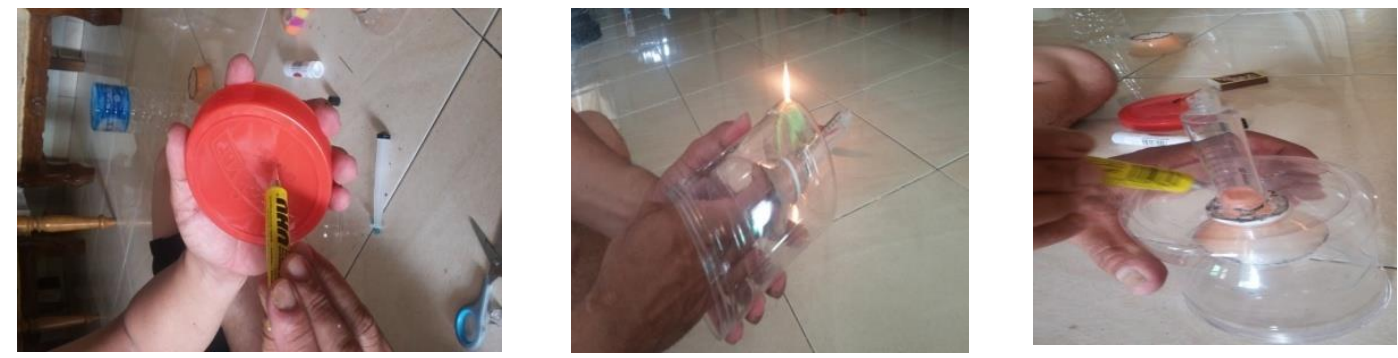

Gambar 9. Langkah ke-7 Pembuatan alat percobaan Ingenhousz 

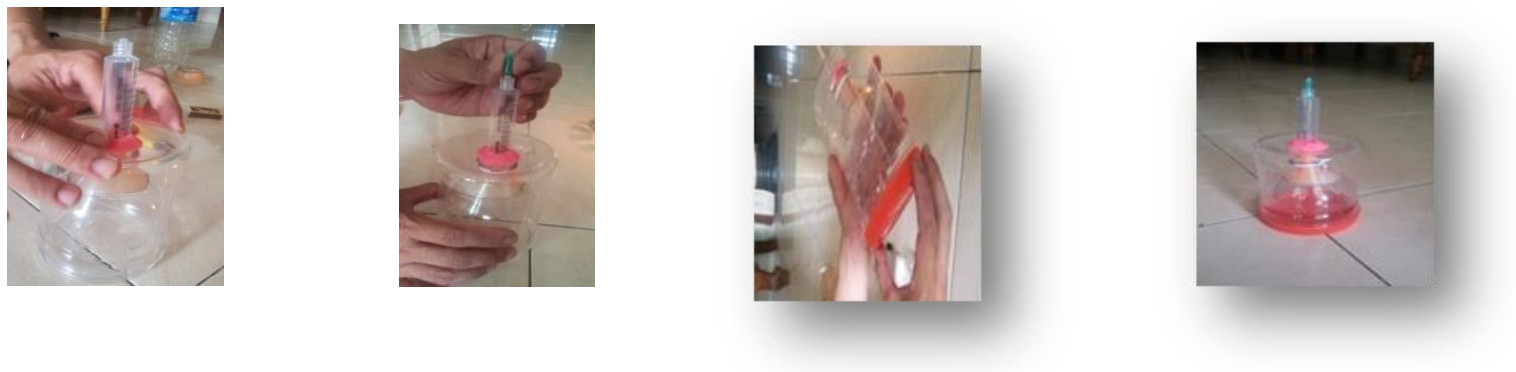

Gambar 10. Langkah ke-8 pembuatan alat percobaan Ingenhousz-selesai

1. Konsep Dasar perencanaan karya inovasi Alat Percobaan Ingenhousz

Pendekatan kerja yang dilakukan dalam perencanaan modifikasi alat Percobaan Ingenhousz tidak terlepas dari teori yang mendasarinya yakni peristiwa Fotosintesis dan Alat Pembuktian hasil Fotosintesis. Fotosintesis berasal dari kata foton adalah cahaya dan sintesis adalah penyusunan. Fotosintesis adalah peristiwa penyusunan zat organik (gula) dari zat anorganik (air, karbondioksida) dengan pertolongan energi cahaya. Oleh karena bahan baku yang digunakan adalah zat karbon (karbondioksida) maka fotosintesis dapat juga disebut asimilasi karbon (Syamsuri, 2007).

Secara singkat persamaan reaksi fotosintesis yang terjadi di alam dapat dituliskan sebagai berikut: cahaya matahari

$6 \mathrm{CO}_{2}+6 \mathrm{H}_{2} \longrightarrow \mathrm{C}_{6} \mathrm{H}_{12} \mathrm{O}_{6}+6 \mathrm{O}_{2}$ Klorofil

Dalam Peristiwa Fotosintesis yang tergambar dari reaksi fotosintesis dia atas bahwa bahan baku fotosintesis adalah karbondoiksida dan air dan sebagai hasil fotosintesis adalah karbohidrat dan oksigen. Peristiwa fotosintesis dapat terjadi karena adanya cahaya dan klorofil. Reaksi fotosintesis terjadi pada membran fotosintesis tumbuhan. Pada tumbuhan, alga dan protista bersel satu (misalnya euglena), semua reaksi fotosintesis terjadi dalam organel sel yang disebut kloroplas. Kloroplas mepunyai sistem membran dalam. Membran ini terorganisasi menjadi kantong pipih berbentuk cakram yang disebut tilakoid. Tumpukan tilakoid disebut grana. Tiap-tiap tilakoid merupakan ruang tertutup dan berfungsi sebagai tempat pembentukan ATP. Disekeliling tilakoid terdapat cairan yang disebut stroma. Stroma mengandung enzim yang berperan dalam reaksi fotosintesis. Oleh karena itu, untuk mengetahui dan membuktikan bahwa hasil dari proses fotosintesis pada tumbuhan menghasilkan $\mathrm{O}_{2}$, maka dilakukanlah percobaan ini Ingenhousz untuk membuktikannya.

Jan Ingenhousz (1799) membuktikan bahwa pada fotosintesis dilepaskan $\mathrm{O}_{2}$. Hal ini dibuktikan dengan percobaannya menggunakan tanaman air Hydrilla vertiolata dibawah corong terbalik. Jika tanaman tersebut kena sinar, maka timbulah gelembung- gelembung gas yang akhirnya mengumpul di dasar tabung reaksi. Gas ini ternyata oksigen.

\section{Bentuk Karya Inovasi yang dirancang}

Dasar kerja pembuatan alat percobaan Ingenhousz hasil modifikasi adalah bentuk perangkat percobaan yang digunakan oleh Jan Ingenhousz. Berikut adalah alat-alat bekas yang kemudian digunakan untuk membentuk Alat Percobaan Ingenhousz pada penelitian ini:

1. Beaker Gelas Besar, di ganti dengan stoples plastik putih transparan lengkap dengan tutupnya.

2. Corong kaca, di ganti dengan corong plastik putih berwarna kecil yang kemudian supaya lingkaranya lebih besar di sambung dengan leher botol sprite 1,5 liter yang sudah di potong, corong ini akan di balik untuk menahan hydrilla verticulata dan mengumpulkan hasil fotosintesis berupa oksigen untuk di alirkan ke dalam tabung reaksi .

3. Tabung reaksi, di ganti dengan tabung spuit atau tabung suntikan ukuran sedang. Tabung spuit dibalik dan cabut jarum suntuk pada bagian atas lalu tutup dengan paravin atau lilin, juga dapat diganti dengan karet penutup. Tabung tersebut di gunakan sebagai tempat naiknya oksigen ke bagian dasar tabung atau dalam kedudukannya pada alat ini adalah pada bagian atas tempat berkumpulnya oksigen hasil fotosintesis, tutup tabung reaksi dapat di buka dan jika bara api di dekatkan dan mengenai oksigen maka beberapa saat bara api membesar.

3. Rancang bangun Modifikasi Alat Percobaan Ingenhousz

Alat dan bahan yang digunakan :

$>$ Stoples Plastik ukuran sedang yang masih baru atau bersih

$>$ tabung spuit

$>$ Botol Aqua putih transparan

$>$ Lilin parafin mainan, lilin bakar

$>$ Gunting

$>$ Lem plastik

$>$ Cutter atau pisau tajam

Cara Pembuatan Alat :

1) Panaskan ujung pisau atau cutter, setelah cukup panas lubangi bagian dasar dari stoples plastik 
dengan lingkaran seluas lingkaran tabung spuit atau selang transparan yang di gunakan (Gambar 3).

2) Ambil botol aqua warna putih, potong bagian atas botol $\pm 10 \mathrm{~cm}$ dibawah mulut botol (Gambar 4).

3) Mempersiapkan corong plastik, potong telinga corong kurang lebih $5 \mathrm{~cm}$ dari dasar corong (Gambar 5).

4) Susunlah corong plastik dengan leher botol aqua dengan posisi corong plastik pada bagian bawah, lem dan tunggu sampai merekat dan kering (Gambar 6).

5) Ambil spuit, lepaskan pompa dan jarum dari bagian ujungnya, kemudian potong plastik yang melebar pada mulut spuit, kemudian beri lem pada ujung bagian dalam (Gambar 7).

6) Lem bagian luar dari leher corong kemudian pasangkan mulut tabung spuit ke tangkai corong plastic (Gambar 8).

7) Bukalah tutup stoples plastik, lem lubang kecil pada tutup stoples, masukkan corong tabung spuit melalui mulut stoples, keluarkan ujung tabung melalui lobang pada dasar toples (Gambar 9).

8) Pasanglah lilin parafin pada batas antara tabung spuit dengan lobang stoples, pasang tutup stoples dan tutup lubang pada ujung atas spuit dengan penutup khusus atau lilin parafin (Gambar 10).

\section{Uji Coba Alat Percobaan Ingenhousz}

Pada perencanaan awal desain Alat Percobaan Ingenhousz yang dirancang oleh penulis bahwa gelas beaker sebagai dasar dari alat percobaan di ganti dengan dasar dari botol aqua besar, sedangkan tabung reaksi diganti dengan tabung reaksi yang dasarnya jebol atau pecah bagian dasarnya. Pada ujung tabung reaksi dipasang selang putih kecil dan diberi karet penutup. Uji coba pembuatan alat dilakukan di kelas VIII-1 seperti terlihat pada Gambar 11 di bawah ini. Semua kelompok belajar sudah membuat alat sesuai dengan petunjuk yang telah disusun oleh peneliti dengan hasil cukup baik Setelah pembuatan alat selesai maka dilakukan uji coba penggunaan alat. Dari hasil uji coba ternyata ada beberapa kendala yang dihadapi dalam pembuatan dan penggunaan antara lain :

1. Selang kecil yang telah di pasang pada ujung tabung reaksi lepas dan tidak kuat

2. Ternyata tabung reaksi yang digunakan ada yang retak tidak telihat oleh mata langsung sehingga tabung bocor

3. Pada percobaan akhir untuk melihat adanya pembakaran sempurna mengalami kendala karena susahnya melepas sumbat karet pada ujung selang kecil

4. Waktu yang digunakan siswa untuk memasukkan tumbuhan hydrilla ke bawah corong plastik masih terlalu lama sehingga menyita waktu pembelajaran.
5. Dari catatan dialog guru dengan siswa setelah pembelajaran berakhir ,siswa menyatakan bahwa pembelajaran menyenangkan tetapi mereka merasa masih belum mampu tepat waktu melaksanakan percobaan karena kurang terampil menggunakan alat. Demikian juga mereka tidak dapat membuktikan fakta sesuai petunjuk praktikum karena alat yang mereka buat tidak memungkinkan untuk membuktikan itu,seperti karena karet pada ujung selang lepas, ada juga selang yang sulit di buka, bahkan ada tabung reaksi yang bocor.

Guna mengatasi kendala penggunaan alat di atas maka peneliti berdiskusi dengan siswa dan guru pengampu pelajaran IPA yang lain sehingga di dapat solusi bahwa:

1. Tabung reaksi di ganti dengan tabung spuit yang ada penutupnya.

2. Selang kecil pada ujung tabung reaksi di lepas, tidak di gunakan

3. Untuk penutup tabung reaksi digunakan lilin parafin yang mudah di lepas

4. Agar mempermudah anak memasukkan tumbuhan hydrilla sp, maka di gunakan stoples plastik trnsparan terbalik yang bisa di buka tutup.

Hasil dari refleksi diatas disusun kembali menjadi lembar kegiatan Pembuatan Alat Percobaan Ingenhousz dan juga lembar kerja percobaan Ingenhousz, Peneliti terlebih dahulu membuat alat dan melakukan uji coba alat percobaan seperti ditunjukkan pada Gambar 12.

Dampak yang diharapkan dari penggunaan alat Percoban Ingenhousz hasil modifikasi adalah :

1. Untuk mengatasi keterbatasan jumlah alat yang tersedia di laboratorium

2. Guna mendapatkan alat yang murah

3. Alat yang mudah di dapat dari lingkungan tempat tinggal siswa

4. Alat yang dapat di produksi oleh siswa sendiri dengan mudah, dengan demikian siswa mendapat pengalaman belajar dalam membuat alat praktikum

5. Memunculkan rasa tanggung jawab siswa dalam memelihara alat-alat laboratorium

6. Meningkatkan efisiensi pembelajaran karena dengna menggunakan alat percobaan ingenhousz mempermudah siswa melaksanakan praktikum sehingga praktikum dapat mempersingkat waktu pembelajaran serta pembelajaran berlangsung dengan menyenangkan.

7. Meningkatkan efektivitas pembelajaran karena pelaksanaan percobaan dengan menggunakan alat Percobaan Ingenhousz dapat memberi kesempatan siswa untuk membuktikan teori dan menemukan fakta dengan demikian hasil belajar siswa tercapai.

C. Aplikasi Praktis Untuk Pembelajaran 
Karya inovasi alat pembelajaran berupa modifikasi perangkat Percobaan Ingenhousz diharapkan dapat digunakan untuk mempermudah pelaksanaan percobaan Ingenhouz. Alat yang telah diperbaharui tersebut memiliki kepraktisan dalam penggunaan karena alat tersebut tidak perlu dirangkai lagi oleh siswa tetapi menjadi satu kesatuan perangkat yang utuh dan siap digunakan. Demikian juga untuk mempermudah siswa memasukkan tumbuhan hydrilla verticillata ke bawah corong, maka tumbuhan dan $\mathrm{NaHCO}_{3}$ dimasukkan melalui bawah perangkat percobaan, yakni mulut stoples yang sudah dibalik.

Sebelum pembelajaran dengan menggunakan alat hasil modifikasi percobaan Ingenhousz dilaksanakan, guru menyusun skenario pembelajaran yang akan dilaksanakan, yaitu:

$>$ Membuat rencana program pengajaran (RPP)

$>$ Mempersiapkan lembar kerja siswa untuk percobaan Ingenhousz yang akan diajarkan

> Mempersiapkan lembar kerja siswa untuk pembuatan alat percobaan Ingenhousz yang akan diajarkan

> Mempersiapkan instrumen penilaian untuk tes pengetahuan dan keterampilan

> Mempersiapkan lembar penilaian produk

> Mempersiapkan format lembar observasi dan kuisioner untuk mengetahui aktivitas dan respon siswa

> Membentuk kelompok belajar yang heterogen

$>$ Melaksanakan proses pembelajaran melalui penggunaan alat percobaan Ingenhousz hasil modifikasi dan selama kegiatan berlangsung, peneliti dan observer melakukan pengamatan terhadap aktivitas siswa.

> Setelah proses belajar mengajar selesai dilaksanakan, dilakukan penyebaran angket untuk mengetahui respon siswa

\section{DATA HASIL APLIKASI PRAKTIS INOVASI PEMBELAJARAN}

Penelitian mengenai efektivitas dan efisiensi pelaksanaan percobaan Ingenhousz dengan menggunakan Alat percobaan ingenhousz hasil modifikasi dilaksanakan di kelas VIII-3 SMP Negeri 4 Palangka Raya. Siswa di kelas VIII-3 terdiri dari 14 orang pria dan 9 orang wanita dengan tingkat kemampuan heterogen. Penelitian ini dilaksanakan pada bulan November 2019 minggu ke 4 dan dilaksanakan dalam 2 kali pertemuan. pertemuan 1 dilaksanakan pada hari kamis 21 November 2019 dan pertemuan ke 2 pada hari kamis 28 November 2019.

Selama proses praktikum menggunakan alat percobaan ingenhousz hasil modifikasi berlangsung, dilakukan proses pengamatan terhadap aktivitas siswa. Demikian juga dilaksanakan penilian keterampilan dan penilaian pengetahuan. Juga diukur waktu pembelajaran yang terdiri dari waktu pembelajaran.
Pada Pertemuan I dilaksanakan pembelajaran dengan metode percobaan yakni melaksanakan prosedur percobaan Ingenhousz dengan menggunakan perangkat percobaan ingenhousz yang ada tersedia di laboratorium SMP Negeri 4 Palangkaraya. Berikut hasil belajar siswa untuk pertemuan I.

Hasil belajar pertemuan I seperti tertera dalam Tabel 1 di bawah, refleksi dengan teman sejawat yakni guru IPA yang juga membantu menjadi obserbver. Dari hasil refleksi maka alat percobaan ingenhousz mengalami perbaikan baik perangkat penyusun alat maupun rancang bangun. Maka peneliti mendesain serta membuat contoh alat percobaan Ingenhousz yang baru. Alat Percobaan Ingenhousz tersebut di sosilisasikan kepada siswa kelas VIII-1 dan guru menugaskan kepada siswa untuk membuatnya. Alat percobaan Ingenhousz yang telah mereka buat selanjutnya di uji cobakan di kelas VIII-1, namun ternyata pelaksanaan pembelajaran masih belum efektif dan efisien. Catatan dari pelaksanaan uji coba alat dipelajari oleh peneliti dan direfleksikan kembali sehingga dilakukan modifikasi lanjutan dengan sedikit pengembangan. Peneliti kembali membuat alat Percobaan Ingenhousz, selanjutnya di sosialisasikan di kelas VIII-3, kemudian siswa dengan bimbingan guru membuat alat percobaan, masing-masing kelompok yang terdiri dari 6 kelompok membuat 1 alat percobaan. Pada Pertemuan 2 alat Percobaan itu digunakan dalam pembelajaran. Setelah Pembelajaran berakhir disebarkan angket respon siswa terhadap pembelajaran menggunakan alat percobaan Ingenhousz. Berikut Hasil Belajar Pada Pertemuan ke-2 dengan menggunakan Alat Percobaan Hasil modifikasi dapat dilihat pada Tabel 2 di bawah.

\section{Analisis Hasil Aplikasi Praktis Inovasi Pembelajaran}

Dampak dari penggunaan Alat Percobaan Ingenhousz hasil modifikasi ke-2 ternyata cukup signifikan. Data yang telah didapatkan dari hasil tes, observasi, dan penyebaran angket siswa diolah dalam bentuk rata-rata hasil tes dan persentase pencapaian hasil belajar secara klasikal. Hasil pencapaian siswa dalam pembelajaran tersebut di bandingkandan dapat dilihat dalam Tabel 3 di bawah.

Berdasarkan data, pembelajaran IPA khususnya pada materi Fotosintesis dengan memanfaatkan alat Percobaan Ingenhousz hasil modifikasi memberi dampak positif dalam pelaksanaan pembelajaran, khususnya untuk pelaksanaan percobaan Ingenhousz, Hasil tes pengetahuan menunjukan meningkatnya nilai rata-rata kelas dari 56,69 menjadi 80,86 , Nilai rata-rata keterampilan meningkat dari 63,00 menjadi 78,52, sedangkan nilai rata-rata aktivitas siswa meningkat dari 2,57 menjadi 2,86 yang menunjukkan siswa semakin terlibat dalam proses pembelajaran. Sedangkan persentase ketuntasan kelas juga meningkat. Persentase ketuntasan kelas untuk pengetahuan meningkat dari $34 \%$ menjadi $91,30 \%$, persentase 
ketuntasan kelas untuk keterampilan meningkat dari $22,00 \%$ menjadi $95,65 \%$, sedangkan persentase ketuntasan kelas untuk aktivitas meningkat dari $85,71 \%$ menjadi 95\%. Peningkatan semua aspek penilaian yang terdiri dari pengetahuan, keterampilan dan hasil obserbvasi aktivitas siswa menunjukkan bahwa penggunaan alat percobaan Ingenhousz hasil modifikasi mampu memfasilitasi siswa untuk menemukan fakta sendiri menganalisis dan memberi kesimpulan dari apa yang dia temukan serta mengaitkannya dengan teori yang ada, hal tersebut mengakibatkan pemahaman siswa meningkat dan fakta yang siswa temukan akan lebih di ingat. Peningkatan hasil belajar tersebut juga akibat dari siswa semakin terlibat dari kegiatan belajar mengajar. Dari ketiga aspek penilaian tersebut di atas aspek yang paling besar peningkatannya adalah persentase ketuntasan kelas untuk keterampilan siswa melaksanakan percobaan. Tentu hal ini merupakan dampak dari penggunaan alat percobaan Ingenhousz yang dalam hal ini mempermudah mereka melaksanakan paraktikum. Tercapainya tujuan pembelajaran dengan keberhasilan siswa dalam pembelajaran baik dari aspek pengetahuan, keterampilan dan aktivitas menunjukkan bahwa penggunaan alat praktikum percobaan Ingenhousz hasil modifikasi meningkatkan efektifitas Pembelajaran.

Dalam pembelajaran ini juga siswa diberi kesempatan untuk membuat produk berupa penggandaan alat Percobaan Ingenhousz. Hasil ratarata penilaian produk media percobaan yang di hasilkan oleh siswa adalah 76,21\% ini menunjukkan siswa sudah menghasilkan karya yang cukup baik dan
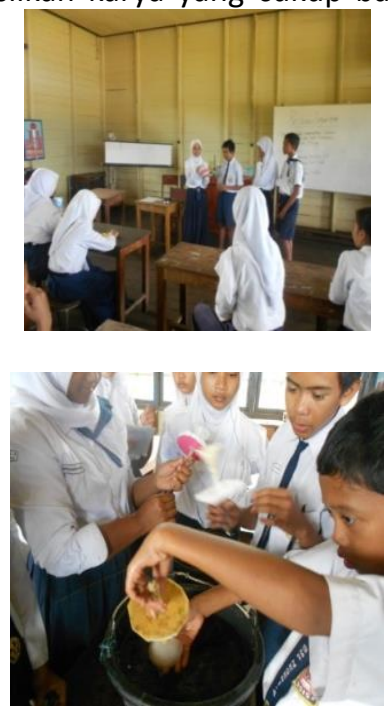

dapat digunakan dalam percobaan yang mereka lakukan. Siswa dapat membuat media pembelajaran sendiri dari bahan-bahan bekas, murah dan mudah di dapat dari lingkungannya sendiri. Hasil penyebaran angket respon siswa terhadap pembelajaran menghasilkan persentase respon sebesar $89 \%$ hal ini menunjukkan kriteria sangat baik artinya seluruh kegiatan pembelajaran dengan menggunakan alat percobaan Ingenhousz menarik, memberi semangat belajar, mempermudah pelaksanaan percobaan, mengaktifkan siswa untuk terlibat belajar, memberi kesempatan berbagi tugas dalam kelompok. Pembelajaran secara berkelompok untuk membuat alat percobaan Ingenhousz dan melaksanakan percobaan secara bersama-sama dapat membangkitkan keingintahuan dan kerja sama di antara siswa serta mampu menciptakan kondisi yang menyenangkan. Hal ini sesuai dengan tuntutan dalam kurikulum tingkat satuan pendidikan (KTSP) bahwa pelaksanaan proses pembelajaran mengikuti standar kompetensi, yaitu: berpusat pada siswa; mengembangkan keingintahuan dan imajinasi; memiliki semangat mandiri, bekerja sama, kompetisi dan mencipta. Kemampuan siswa untuk membuat alat percobaan Ingenhousz dari bahan yang murah dan mudah di dapat, serta respon siswa yang sangat positip terhadap pembelajaran, memberi kesempatan siswa banyak terlibat dalam belajar dan memberi hasil belajar yang baik dengan penghematan waktu yakni dari 60 menit menjadi 45 menit, hal ini menggambarkan bahwa pelaksanaan percobaan menggunakan alat percobaan Ingenhousz dapat meningkatkan efisiensi pelaksanaan pembelajaran khusus pelaksanaan percobaan ingenhousz.
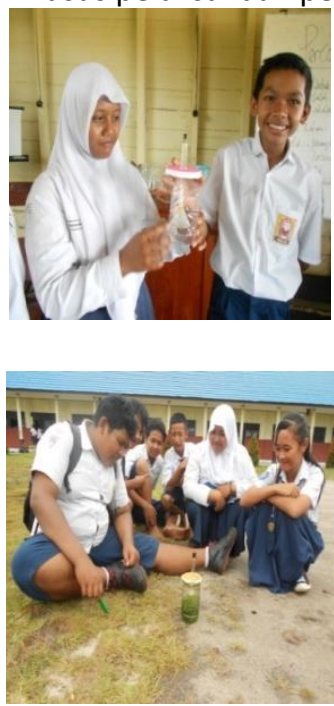

Gambar 11. Kegiatan Pembuatan alat dan pembelajaran uji coba pertama penggunaan Alat Percobaan Ingenhousz 

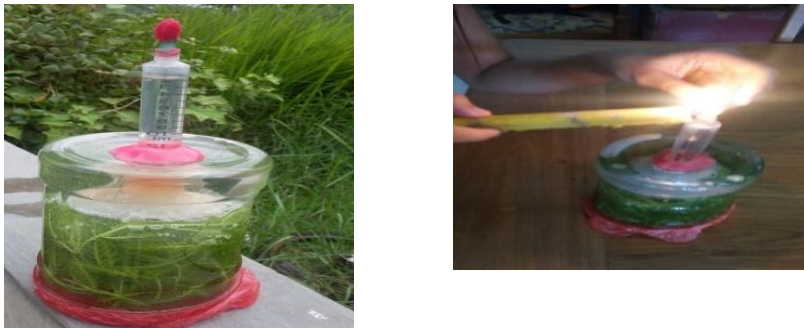

Gambar 12. Uji Coba ke-2 Penggunaan Alat Percobaan Ingenhouzs

Tabel 1. Tabel Hasil Pembelajaran I

\begin{tabular}{|c|c|c|c|c|c|c|}
\hline No & Aspek Penilaian & $\begin{array}{c}\text { Nilai } \\
\text { Rerata } \\
\text { Kelas } \\
\end{array}$ & $\begin{array}{c}\text { Ketuntasan } \\
\text { kelas (\%) }\end{array}$ & Kriteria & $\begin{array}{l}\text { Catatan } \\
\text { Waktu }\end{array}$ & Keterangan \\
\hline 1 & Pengetahuan & 56,69 & $34 \%$ & $\begin{array}{l}\text { Pembelajaran } \\
\text { tidak berhasil } \\
\text { secara klasikal }\end{array}$ & \multirow{3}{*}{60 menit } & \multirow{3}{*}{$\begin{array}{c}\text { Pelaksanaan } \\
\text { pembelajaran } \\
\text { tidak efektif dan } \\
\text { efisien }\end{array}$} \\
\hline 2 & Keterampilan & 63,00 & $22 \%$ & $\begin{array}{c}\text { Perrcobaan } \\
\text { tidak berhasil } \\
\text { secara klasikal }\end{array}$ & & \\
\hline 3 & Aktivitas & 2,57 & $85,71 \%$ & Baik & & \\
\hline
\end{tabular}

Tabel 2. Hasil Belajar Siswa Pada Pertemuan ke-2

\begin{tabular}{|c|c|c|c|c|c|c|}
\hline No & Aspek Penilaian & $\begin{array}{l}\text { Nilai } \\
\text { Rerata } \\
\text { Kelas }\end{array}$ & $\begin{array}{c}\text { Ketuntasan } \\
\text { kelas (\%) }\end{array}$ & Kriteria & $\begin{array}{l}\text { Catatan } \\
\text { Waktu }\end{array}$ & Keterangan \\
\hline 1 & Pengetahuan & 80,86 & $91,30 \%$ & $\begin{array}{l}\text { Pembelajaran } \\
\text { berhasil secara } \\
\text { klasikal }\end{array}$ & \multirow{5}{*}{45 menit } & \multirow{5}{*}{$\begin{array}{l}\text { Pelaksanaan } \\
\text { pembelajaran } \\
\text { berjalan secara } \\
\text { efektif dan } \\
\text { efisien }\end{array}$} \\
\hline 2 & Keterampilan & 78,52 & $95,65 \%$ & $\begin{array}{l}\text { Perrcobaan } \\
\text { berhasil secara } \\
\text { klasikal }\end{array}$ & & \\
\hline 3 & Produk & \multicolumn{2}{|c|}{76,21} & Baik & & \\
\hline 4 & Aktivitas & 2,85 & $95 \%$ & Baik & & \\
\hline 5 & Respon siswa & \multicolumn{2}{|c|}{$89 \%$} & Sangat baik & & \\
\hline
\end{tabular}

Tabel 3 Perbandingan Hasil belajar pertemuan I dan Pertemuan II

\begin{tabular}{|c|c|c|c|c|c|c|}
\hline \multirow{3}{*}{$\begin{array}{c}\text { Aspek } \\
\text { penilaian } \\
\text { Pengetahuan }\end{array}$} & \multirow{2}{*}{\multicolumn{2}{|c|}{$\begin{array}{c}\text { Nilai Rerata } \\
\text { kelas }\end{array}$}} & \multicolumn{4}{|c|}{ Ketuntasan } \\
\hline & & & \multirow[t]{2}{*}{ Peningkatan } & \multicolumn{2}{|c|}{ kelas } & \multirow[t]{2}{*}{ Peningkatan } \\
\hline & $\mathrm{P}-1$ & P-2 & & P-1 & P-2 & \\
\hline Pengetahuan & 56,69 & 80,86 & 24,17 & $34 \%$ & $91,30 \%$ & $57,30 \%$ \\
\hline Keterampilan & 63,00 & 78,52 & 15,52 & $22 \%$ & $95,65 \%$ & $73,65 \%$ \\
\hline Aktivitas & 2,57 & 2,85 & 0,28 & $85,75 \%$ & $95 \%$ & $9,25 \%$ \\
\hline Produk & \multicolumn{2}{|c|}{76,21} & - & \multicolumn{2}{|c|}{ - } & - \\
\hline Respon & \multicolumn{2}{|c|}{-} & - & \multicolumn{2}{|c|}{$89 \%$} & - \\
\hline Waktu & \multicolumn{3}{|c|}{60 menit } & \multicolumn{3}{|c|}{45 menit } \\
\hline
\end{tabular}

\section{KESIMPULAN}


Berdasarkan hasil penelitian ini maka dapat di simpulkan bahwa:

1. Penggunaan alat percobaan Ingenhousz hasil modifikasi dapat meningkatkan efektivitas pelaksanaan pembelajaran khususnya percobaan ingenhousz pada siswa kelas VIII-3 SMP Negeri 4 Palangka Raya

2. Penggunaan alat percobaan Ingenhuosz hasil modifikasi dapat meningkatkan efisiensi pelaksanaan percobaan Ingenhousz pada siswa kelas VIII-3 SMP Negeri 4 Palangka Raya

3. Penggunaan Alat Percobaan Ingenhousz dapat meningkatkan respon belajar siswa kelas VIII-3 di SMP Negeri 4 Palangka Raya

\section{DAFTAR PUSTAKA}

Aviantarani, Devi. 2011. "Upaya Meningkatkan Hasil Belajar dan Respon Siswa Kelas VII dengan Menggunakan Computer Assisted Instruction (CAI) pada Konsep Ekosistem: Penelitian Tindakan Kelas di Kelas VII SMP Negeri 5 Bandung". Skripsi. FPMIPA: Universitas Pendidikan Indonesia (UPI).

Dimyati. 2004. Belajar dan Pembelajaran. Jakarta:Depdikbud.

Djamarah, S.B. 2008. Prestasi Belajar dan Kompetensi Guru. Surabaya: Usaha Nasional.

Firdaus. 2009. Upaya Peningkatan Hasil Belajar Matematika Siswa Melalui Penerapan Model Pembelajaran ARIAS Pada Materi Bentuk Pangkat, Sksr, dan Logaritma Di Kelas X SMAN 4 Bengkulu. Skripsi. Universitas Bengkulu.

Gultom, Lena. 2008. Upaya Meningkatkan Hasil Belajar Matematika dengan Menggunakan Alat Peraga Untuk Penanaman Konsep Matematika Di Kelas V A SDN 27 Kota Bengkulu. Skripsi. Universitas Bengkulu
Hamalik, Oemar. 2001. Psikologi Belajar dan Mengajar. Bandung. Sinar Baru

Mustapa, Ali. 2011. “Pengaruh Penggunaan Multimedia Interaktif Terhadap Peningkatan Motivasi Siswa dalam Pembelajaran Bahasa Arab Kelas V MIN Malang 2". Tesis. PGMI: Universitas Islam Negeri Maulana Malik Ibrahim Malang.

Purba, Michael. 2007. IPA KIMIA untuk SMP Kelas VIII. Jakarta. Penerbit Erlangga

Sardiman, Arif. S. Dkk. 2009. Media Pendidikan. Jakarta. Rajawali Pers

Satri, Jaka. 2008. Peningkatan Motivasi dan Hasil Belajar Kimia Siswa Melalui Penggunaan Model Atom Hidrokarbon dari Kardus pada Pokok Bahasan Hidrokarbon. Makalah. Bengkulu

Satri, Jaka. 2004. Upaya Meningkatkan Motivasi Dan Prestasi Belajar Kimia Siswa Pada Pokok Bahasan Materi Dan Perubahannya Melalui Penggunaan Perangkat Kit Praktikum Di Kelas I.E SMA Negeri 3 Kota Bengkulu. Skripsi. Universitas Bengkulu.

Susilana, Rudi dan Riyana, Cepi. 2008. Media Pembelajaran. Bandung. Wacna Prima

Suryatin, Budi. 2008. Kimia VIII Untuk SMP dan MTs. Jakarta. PT. Gramedia Widiasarana Indonesia.

Sutrisno, Sandra Pratama. 2011. "Pengertian Respon". http://pratamasandra.wordpress.com/2011/05/11/ pengertian-respon/ diunduh tanggal 5 Juni 2015

Tim Abdi Guru, 2007. IPA Terpadu Untuk SMP Kelas VIII KTSP 2006. Jakarta. Penerbit Erlangga.

Widyantini dan Sigit. 2010. Pemanfaatan Alat Peraga Dalam Pembelajaran Matematika SMP. Yogyakarta. Departemen Pendidikan Nasional. 